\author{
Original Article
}

\title{
Description of Lutziella swatensis sp.n. (Trematoda: Dicrocoelidae) from Rattus rattus in Swat, Pakistan
}

\author{
Descrição de Lutziella swatensis sp.n. (Trematoda: Dicrocoelidae) de Rattus rattus em \\ Swat, Paquistão
}

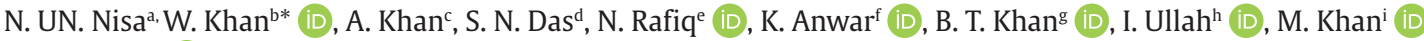 \\ and A. Alami iD \\ a University, of Karachi, Vertebrate Pest Control Institute - VPCI, Southern Zone-Agricultural Research Centre - SARC, Pakistan Agricultural Research \\ Council - PARC old Block 9 E'10, Karachi, Pakistan \\ ${ }^{\mathrm{b}}$ University of Malakand Chakdara Lower Dir, Department of Zoology, Laboratory of Parasitology, Khyber Pakhtunkhwa, Pakistan \\ ' University of Karachi, Crop Diseases Research Institute - C.D.R.I, Southern Zone-Agricultural Research Centre - SARC, Pakistan Agricultural Research \\ Council - PARC, Karachi, Pakistan \\ dUniversity of Sindh, Department of Zoology, Hyderabad, Pakistan \\ e Abdul Wali Khan University, Department of Zoology, Mardan, Pakistan \\ ${ }^{\mathrm{f}}$ Veterinary Research and Diseases Investigation Center, Department of Livesstock and Dairy Development, Balogram Swat, Khyber Pakhtunkhwa, Pakistan \\ g University of Buner, Department of Zoology, Buner, Pakistan \\ hUniversity of Agriculture Peshawar, Department of Veterinary and Animals Sciences, Peshawar, Pakistan \\ i University of Peshawar, Department of Zoology, Khyber Pakhtunkhwa, Pakistan \\ ${ }^{\mathrm{j}}$ Hazara University Mansehra, Department of Zoology,Mansehra, Pakistan
}

\begin{abstract}
A new species of the genus Lutziella (Rohde, 1966) Yamaguti, 1971 is described here and named Lutziella swatensis sp.nov. from the liver of rat (Rattus rattus L.). The new species is characterized by having body flat, smooth, longer than broad with maximum width at the level of the ovary, oral sucker with weak musculature, pharynx small; eosophagus long; caeca of irregular shape which bifurcate on the anterior border of the ovary in to unequal portions, acetabulum weakly muscular, post-testicular, testes lobed, cirrus pouch somewhat median, small in size containing winding seminal vesicle, prostatic complex and short ejaculatory duct. Genital pore median. Ovary post testicular, submedian; seminal receptacle overlapping ovary, laurer's canal present. Vitellaria follicular extending on each side from almost the level of testes to anterior portion of posterior half of the body. Uterus filled with eggs occupying most of the body, eggs oval rather small, numerous, brownish in colour, excretory vesicle tubular with terminal pore. Lutziella swatensis n. sp. is the second species of the genus known from Pakistan as well as the second species described from murid rodents in the world.
\end{abstract}

Keywords: Lutziella swatensis sp. nov, Rattus rattus, Trematoda, Dicocoelids, Pakistan.

\begin{abstract}
Resumo
Uma nova espécie do gênero Lutziella (Rohde, 1966) Yamaguti, 1971 é descrita aqui e denominada Lutziella swatensis sp.nov. do fígado do rato (Rattus rattus L.). A nova espécie é caracterizada por ter corpo liso, liso, mais longo que largo com largura máxima ao nível do ovário, otário oral com musculatura débil, faringe pequena; eosôfago longo; ceco de forma irregular que se bifurca na borda anterior do ovário em porções desiguais, acetábulo fracamente muscular, pós-testicular, testículos lobados, bolsa cirrus um pouco mediana, pequeno em tamanho contendo vesícula seminal sinuosa, complexo prostático e ducto ejaculatório curto. Mediana dos poros genitais. Ovário pós testicular, submediano; ovário sobreposto do receptáculo seminal, canal de laurer presente. Vitellaria folicular que se estende de cada lado de quase o nível dos testículos para a porção anterior da metade posterior do corpo. Útero cheio de ovos que ocupam a maior parte do corpo, oval ovos bastante pequenos, numerosos, de cor acastanhada, vesícula excretor tubular com poro terminal. Lutziella swatensis n. sp. é a segunda espécie do gênero conhecida do Paquistão, bem como a segunda espécie descrita de roedores do mundo.
\end{abstract}

Palavras-chave: Lutziella swatensis sp. nov, Rattus rattus, Trematoda, Dicocoelids, Paquistão.

*e-mail: walikhan.pk@gmail.com

Received: June 11, 2019 - Accepted: April 13, 2020

This is an Open Access article distributed under the terms of the Creative Commons Attribution License, which permits unrestricted use, distribution, and reproduction in any medium, provided the original work is properly cited. 


\section{Introduction}

Rats are capable to harbor various pathogens, among which certain species of zoonotic parasites are included. A long-term detection of parasite fauna of rats has sporadically been carried out in Pakistan (Farooq and Yousaf, 1986; Mehrunnisa and Shimi, 1986; Shafi et al., 1986; Shafi et al., 1982; Noor Un Nisa et al., 2013; Khan et al., 2021). Similar studies have also been conducted outside Pakistan as Chaisiri et al. (2009); Milazzoc et al. (2010); Kifune et al. (2001); Namue and Wangsawad (2011); Tenora et al. (1983); Wiroreno et al. (1987). Abundance of these vertebrate pests is of great importance as regards public health issue. The present paper is focused on a digenean trematode Lutziella swatensis sp.nov. obtained during a two years study on rats over the decades in the country. Herein we describe this occurrence in Rattus rattus pest of agricultural importance in the region with specific note on its morphological description. This is the dicrocoelidean flatworm, can infect human through consumption of infected murine food items, and has never been observed in Pakistan.

Species of the genus Lutziella (Rohde, 1966) Yamaguti, 1971 are parasites of bats and small mammals including rodents. However the taxonomy and distribution of these trematodes are poorly studied in the world and only one species of this genus, Lutziella (lutztrema) microacetabularae (Un-Nisa et al., 2013) has been reported from rats, Rattus rattus of Swat, Khyber Pakhtunkhwa, Pakistan. The helminth fauna of Swat district, Pakistan has not been studied in detail, a survey was conducted in March 2011 to 2013 record the helminth parasites of Rat (Rattus rattus $\mathrm{L}$.). During this study ten trematodes belonging to the genus Lutziella (Rohde, 1966) Yamaguti, 1971 were recorded which are being described in detail.

As part of long term study of the helminth parasites of rats, R.rattus have been collected regularly, from different agricultural fields of district Swat, Khyber Pakhtunkhwa, Pakistan. These materials were utilized to prepare the final description of Lutziella given in the result section. Comparisons between the species of Lutziella together with the present study have allowed an analysis of the variability in morphology and morphometric between populations of worms. In present study we compared Lutziella microacetabularae from Swat, Pakistan and Eurytrema pancreaticum from Java with the specimens of the present study in order to characterize the specimens. It is cleared from the literature that species of the genus Lutziella having limited biogeography.

\section{Materials and Methods}

Two hundred and sixty nine rats (Rattus rattus L.1758) were captured from different agricultural fields of district Swat, Pakistan and brought to Vertebrate Pest Control Institute, Southern Agricultural Research Centre, Karachi. The rats were anesthetized with chloroform in a vacuum chamber and dissected for the presence of helminth parasites. During the examination ten trematodes belonging to the genus Lutziella Rohde 1966 were recovered from the gall bladder of the hosts. Trematodes collected from the gall-bladder were washed in physiological saline, fixed in hot $4 \%$ formalin and then stored in $70 \%$ ethanol. For light microscopy, trematodes were cleared in lactophenol. Specimens were fixed in FAA solution under slight cover glass pressure, stained in Mayer's carmalum, dehydrated in graded series of ethanol, cleared in clove oil and xylol and mounted in Canada balsam. All measurements are expressed in millimeters unless otherwise stated, and were made as illustrated in Figures 1-2. Drawings were made with a Bausch and Lomb tri-simplex projector. Specimens are in the possession of the first author.

\section{Results}

Lutziella swatensis sp.nov. (Figures 1-2)

Type host: Rattus rattus (L. 1758), Rodentia: Muridae Type locality: Rice fields, Swat, Pakistan

Site of infection: Liver

No. of specimens recovered: 10 from a single host

No. of hosts examined: 269

Prevalence of infection: $3.71 \%$

Etymology: The specific name refers to the municipality of the type locality

\subsection{Description (based on whole mounts of 10 specimens)}

Body flat, smooth, longer than broad measuring 2.68-4.52 (3.08 \pm 0.61$)$, maximum width at the level of the ovary $1.68-2.60(2.09 \pm 0.31)$; Oral sucker with weak musculature measuring $0.12-0.32(0.20 \pm 0.06)$ by 0.12 $0.28(0.20 \pm 0.048)$; pharynx small measuring $0.08-0.16$ $(0.12 \pm 0.02)$ by $0.08-0.12(0.11 \pm 0.01)$. Eosophagus long measuring $0.12-0.45(0.28 \pm 0.1)$ by $0.075-0.15(0.11 \pm 0.01)$. Caeca of irregular shape which bifurcate a little anterior of the ovary in to unequal portions. Acetabulum weakly muscular measuring $0.40-0.68(0.53 \pm 0.01)$ by $0.33-0.45$



1

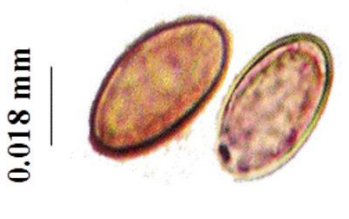

2
Figure 1-2. Lutziella swatensis n.sp. holotype, Photomicrographs. (1) Lutziella swatensis entire specimen; (2) Embryonated eggs enlarged. Note: Entire specimens were measured in millimeter and the eggs were measured in micrometer. 
$(0.38 \pm 0.038)$. Testes lobed at the level of posterior margin of acetabulum, the left measuring $0.32-0.56(0.43 \pm 0.07)$ by $0.24-0.40(0.32 \pm 0.053)$ while the right measuring 0.44 $0.56(0.49 \pm 0.03)$ by $0.20-0.41(0.29 \pm 0.071)$. Cirrus pouch somewhat median, small in size containing winding seminal vesicle, prostatic complex and short ejaculatory duct. Genital pore median a little posterior to the pharynx. Ovary post testicular, submedian; measuring 0.24-0.32 $(0.28 \pm 0.028)$ by $0.20-0.28(0.24 \pm 0.029)$. Seminal receptacle overlapping ovary, laurer's canal present. Vitellaria follicular extending on each side from almost the level of testes to anterior portion of posterior half of the body. Uterus filled with eggs occupying most of the body from the near posterior extremity to pre- testicular zone; eggs small, oval, numerous, brown in colour, measuring 0.034-0.038 $(0.019 \pm 0.003)$ by $0.015-0.026(0.03 \pm 0.001)$. Excretory vesicle tubular with terminal pore (Figures 1-2).

\section{Discussion}

Rohde (1966) erected the genius Lutziella with Lutziella micracetabularae as its type species in Myotis mystacinus (Kuhl) from janda Baik, Pahang, Malaya. Later Yamaguti (1971) amended this genus parasitic in the gall bladder of mammals. Kifune et al. (2001) reported it in the host Murina ryukyuana from Fungawa, Okinawa, Japan. The present specimens differ from $L$. micacetabularae in shape of the testes, in L. micracetabularae they are oval while in the present specimens the testes are lobed. The ovary in the present species are smaller than the testes while in L.micracetabularae it is larger than the testes. Similarly, the vitellaria in the present specimens reach up to the level of acetabulum, while in Lutziella micracetabularae they reach up to the testes level. Previously reported species is Lutziella microacetabularae Rohde (1966), redescribed by Noor Un Nisa et al. (2013) in which acetabulum is smaller than oral suckers but in present species the acetabulum is larger than oral sucker. The present new species L. swatensis is separated from the previously described species in the main diagnostic features described above.

To date little number of species of the genus Lutziella have been reported. The species name refers to the locality of the host. Present species is a first and new host record from Pakistan. Further documentation of the occurrence and distribution of dicrocoelidean trematodes is lacking. Present report appears to be the only known instance of Lutziella swatensis sp.nov. occurring in Pakistan.

\section{Acknowledgements}

The authors thank their colleague Dr. RafiaRehana Ghazi for her co-operation and positive criticism during manuscript preparation.

\section{References}

CHAISIRI, K., HERBRETEAU, V., RIBAS, A., and MORAND, S., 2009. A study of great Bandicoot (Bandictoa indica) and their gastrointestinal helminth from Northern and Northeastern Thailand. France: CERoPath, pp. 165-171, French ANR Biodiversity ANR 07 BDIV 012, Project CERoPath.

FAROOQ M. and YOUSAF, S., 1986. A new trematode from the intestine of Rattus rattus from Campus University of Karachi. Pakistan Journal of Zoology, vol. 18, no. 4, pp. 341-343.

KIFUNE, T., SAWADA, I. and MASAHI, H., 2001. Helminth fauna of Bats in Japan LIV. Medical Bulletin Fukuoka University, vol. 28, no. 1, pp. 1-9.

KHAN, W., NISA, N.N., RAFIQ N., MASOOD, Z., AHMAD, M.S., KABIR, M., GHAFFAR, R., NAZ, A., SHAH, M.I.A. and RAHAMAN, H., 2021. Zoonotic and non-zoonotic helminthes in black rats of rainfed and irrigated areas of Swat, Khyber Pakhtunkhwa, Pakistan. Saudi Journal of Biological Sciences. In press.

MEHRUNNISA, F. and SHIMI, Y., 1986. A new trematode from the intestine of Rattus rattus from University Campus Karachi. Pakistan Journal of Zoology, vol. 18, no. 41, pp. 341-343.

MILAZZOC, C., CAGNIN, M., DIBELLA, C., GERACI, F. and RIBSA, A., 2010. Helminth fauna of Commensal rodents, Mus musculus (Linnaeus, 1758) and Rattus rattus (Linnaeus, 1758) Rodentia, Muridae in Sicily (Italy). Revista Ibero-latinoamericana de Parasitología, vol. 69, no. 2, pp. 194-198.

NAMUE, C. and WANGSAWAD, C., 2011. A survey of helminth infection in rats (Rattus rattus) from Chiang Mai Moat. Chiang Mai, Thailand: Chiang Mai University, pp. 179-183.

NOOR UN-NISA., KHAN, W. and KHAN, A., 2013. Re-description of the Lutztrema (Lutziella) microacetabularae Rohde, 1966 trematode of the family Dicrocoelidae (Looss, 1899). Iranian Journal of Parasitology, vol. 8, no. 3, pp. 491-493. PMid:24454446.

ROHDE, K., 1966. On the trematode genus Lutztrema Travassos, 1941 and Anchitrema Looss, 1899 from Malayan Bats, with discussion of Allometric growth in Helminths. The Helminthological Society of Washington, vol. 33, pp. 184-199.

SHAFI, M.M., GHAZI, R.R., ALI, R. and UN-NISA, N., 1986. Echinostoma bengalensis sp.n. (Trematoda: Echinostomatidae), in rice rat Bandicota bengalensis of Sindh, Pakistan. Proceedings of Parasitology, vol. 2, pp. 28-34.

SHAFI, M.M., REHANA, R. and SAMAD, K., 1982. Catatropis pakistanensis sp.n. (Trematoda: Notocotylidae) with a new host and locality recorded. Pakistan Journal of Agricultural Research, vol. 3, no. 1, pp. 34-39.

TENORA, F., HENTTONEN, H. and HAUKISALMI, V., 1983. On helminthes of rodents in Finland. Annales Zoologici Fennici, vol. 20, pp. 37-45.

WIRORENO, W., CARNEY, W.P. and ANSORI, M., 1987. Description and growth pattern of Eurytrema pancreaticum from Bos indicus from East Java. Proceedings of the Helminthological Society of Washington, vol. 54, no. 1, pp. 73-77.

YAMAGUTI, S., 1971. Synopsis of digenetic trematodes of vertebrates. Tokyo, Japan: Keigaku publishing Co. 